\title{
The expansion mechanism of Himalayan supraglacial lakes: Observations and modelling
}

\section{KA Chikita}

Division of Earth and Planetary Sciences, Graduate School of Science, Hokkaido University, Sapporo, 060-0810, JAPAN

For correspondence, E-mail: chikita@ep.sci.hokudai.ac.jp

In 1950's, due to the glacial retreat, supraglacial ponds started to appear on tongues of glaciers in the Himalayas, and have so far been expanding to the extent of moraine-dammed lakes with ca. $1 \mathrm{~km}^{2}$ in surface area. Since 1960's, the glacial lake outburst flood (GLOF) has occurred once per three years on average by the collapse of end moraine (Yamada 1998). Three morainedammed lakes (Tsho Rolpa and Imja, Nepal and Lugge, Bhutan) were hydrodynamically examined in the past, in order to clarify the expansion mechanism (Chikita et al. 1999, Chikita et al. 2000, Sakai et al. 2000, Yamada et al. 2004).

Figure 1a-c shows the location of Tsho Rolpa and Imja Lakes in Nepal and observation sites on the bathymetric maps. Tsho Rolpa ( $4580 \mathrm{~m}$ asl) is $3100 \mathrm{~m}$ long and $450 \mathrm{~m}$ wide (surface area, $1.39 \mathrm{~km}^{2}$ ) and $131 \mathrm{~m}$ deep at maximum in 1994, which has been expanding from a supraglacial pond of $0.23 \mathrm{~km}^{2}$ in area (Kadota 1994) (Figure 1c). Imja (5010 m asl) appeared as some ponds of $200 \mathrm{~m} \times 50 \mathrm{~m}$ scale in 1960's, and is $1200 \mathrm{~m}$ long, $450 \mathrm{~m}$ wide and $92 \mathrm{~m}$ deep at maximum in 1992 (Yamada and Sharma 1993) (Figure 1b).

I explored physical conditions of Tsho Rolpa Lake in May June 1996 and Imja Lake in July 1997. Figure 2 shows longitudinal distributions of water temperature and turbidity and resultant water density. Here, water density is expressed by "density residue" ó, defined by $\sigma=\left(\rho_{T C P}-1000\right) \times 10$, where $\rho_{T C P}$ is bulk density, a function of water temperature $T$, suspended sediment concentration (SSC) $C$ and water pressure $P$. Water turbidity (ppm) measured was converted into SSC (mg/l) by using significant correlations $\left(r^{2}=0.66\right.$ to 0.89$)$ between turbidity and SSC. As a result, Tsho Rolpa has a wind-mixed layer ca. $25 \mathrm{~m}$ thick below the surface with nearly uniform SSC and density, while Imja does not have such a mixed layer. The wind-mixed layer is formed by wind-forced vertical mixing and wind-driven currents during the leeward setup of surface water. A difference of the spatial distributions between the two lakes suggests that wind velocity over Tsho Rolpa is much higher than that over Imja Lake. Meanwhile, wind velocity measured near or over the end moraine (site M in Figure 1) is not so different between the two lakes, indicating a diurnal valley wind of 2 to $8 \mathrm{~m} / \mathrm{s}$ (northwest and west winds in Tsho Rolpa and Imja, respectively) and a nocturnal mountain wind of 0 to $2 \mathrm{~m} / \mathrm{s}$. The wind velocity is likely controlled by the topography of end moraine; a top of the end moraine upwind of Imja Lake is higher by 10 to $20 \mathrm{~m}$ than the lake level, while that of Tsho Rolpa Lake is almost leveled to the lake surface. It should be noted that in Tsho Rolpa, turbid meltwater inflows at the base of the glacier front, and produces a turbid layer near the bottom. This indicates the occurrence of sediment-laden underflow, originating from near the glacier front. The lake-water temperature ranges from 2 to $8^{\circ} \mathrm{C}$, thus giving water density of 999.85 to $1000.00 \mathrm{~kg} / \mathrm{m}^{3}$ for clear water under $1 \mathrm{~atm}$. Water density is thus always more than $1000 \mathrm{~kg} /$ $\mathrm{m}^{3}$ at SSC of more than $300 \mathrm{mg} / \mathrm{l}$, since the density of suspended sediment is $2760 \mathrm{~kg} / \mathrm{m}^{3}$. Hence, lake water density is controlled by SSC rather than temperature, since dissolved solids are negligible at less than $0.1 \mathrm{mg} / \mathrm{l}$. The spatial patterns of SSC in Figure 2 is thus similar to those of ó. In Imja Lake, there is no bottom layer of high SSC. Thus, neither turbid meltwater inflow nor sediment-laden underflow is produced (Figure 2b). Time series of flow velocity and water temperature were obtained at $25.4 \mathrm{~m}$ in depth at site A of Tsho Rolpa Lake (Figure 3). It is seen that when a valley wind blows on daytime, lake currents prevail in the upwind direction with declining temperature. This indicates that return flow occurred to compensate for the leeward water transfer by the upper wind-driven currents. The decline of water temperature shows the upwelling of the lower cold water by the uplift of the pycnocline at ca. $25 \mathrm{~m}$ depth (Figure 2a). Thus, a nodal line (black circle in Figure 4) exists on the pycnocline uplake of site A (white circle in Figure 4) during the leeward setup.

A conceptual model of hydrodynamics in Tsho Rolpa is shown in Figure 4. Strong valley winds diurnally blow along the apse line of the lake, and produce wind-driven currents and return flow (vertical water circulation). Meanwhile, turbid

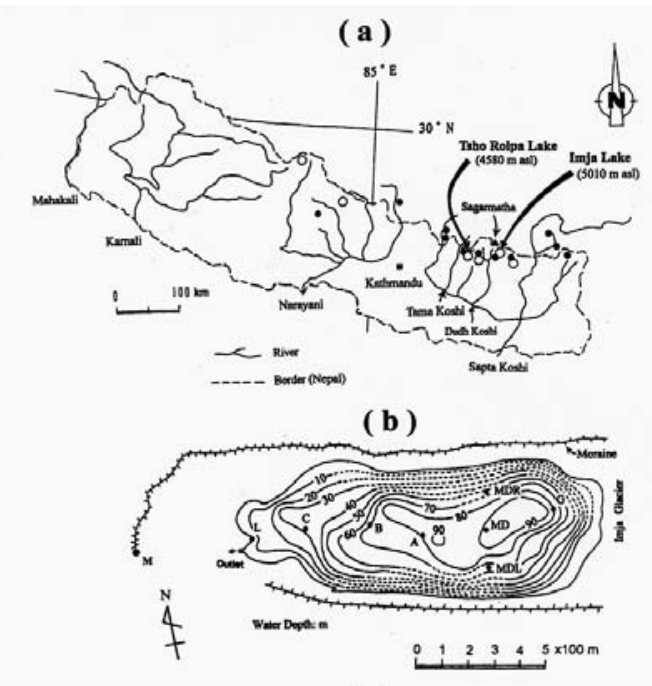

(c)

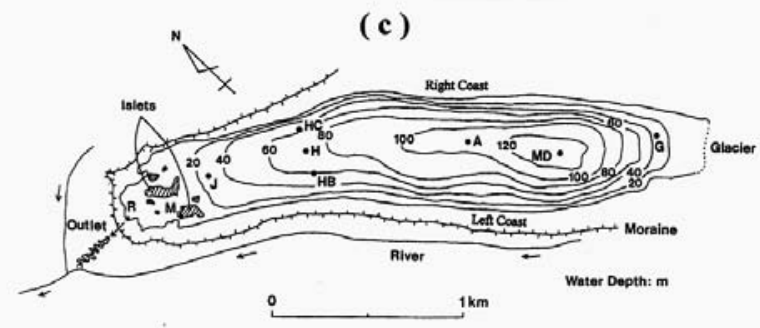

FIGURE 1. (a) Index map of Nepal with locations of lakes studied. The bathymetry and observation sites are given for (b) Imja and (c) Tsho Rolpa Lake. A weather station is at site M in (b) and (c) 

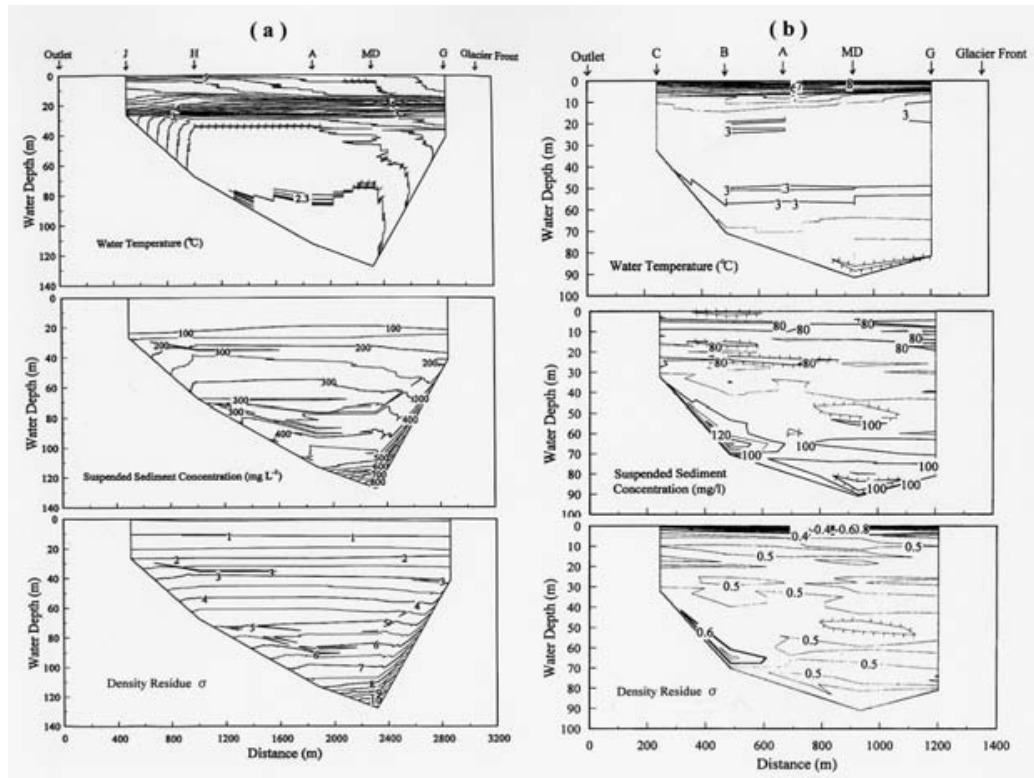

FIGURE 2. Longitudinal distributions of water temperature, suspended sediment concentration (SSC) and density residue in (a) Tsho Rolpa and (b) Imja Lakes

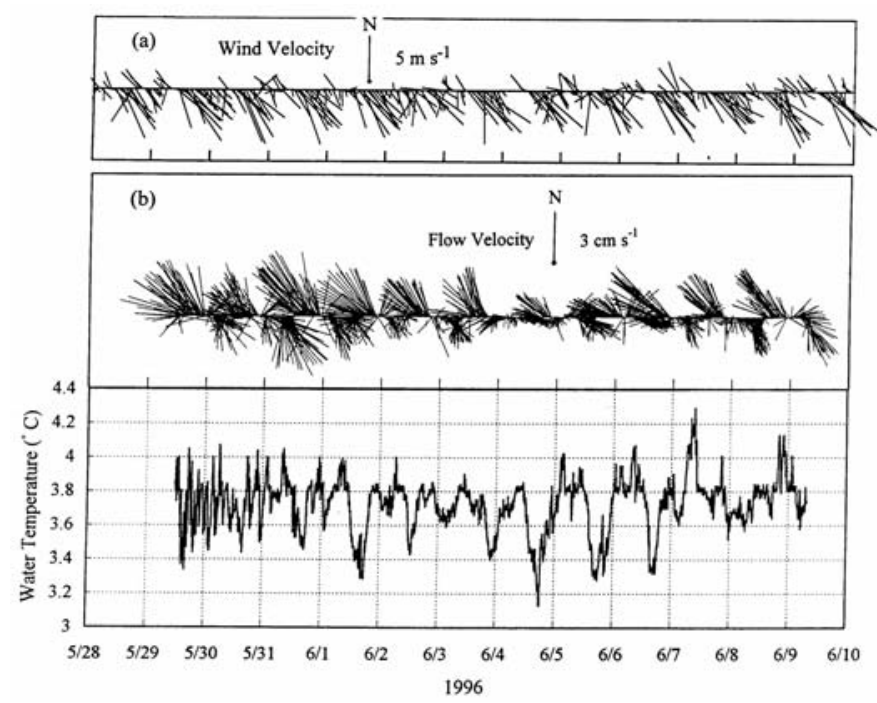

FIGURE 3. Temporal variations of (a) wind velocity at site $M$ and (b) flow velocity and water temperature at site $\mathrm{A}$ (25.4 $\mathrm{m}$ deep) (see Figure 1 for location) meltwater inflow initiates sediment-laden underflow near the glacier front, which establishes the inner density structure by bifurcation into turbid interflows and consequently limits the vertical wind circulation to the upper layer. The vertical water circulation exalts the ice melt at the base of the glacier front and induces calving at the glacier front, since the radiation-heated surface water is transported toward the glacier front by the wind-driven currents, and then the water cooled by the ice melt is moved toward the outlet by return flow. For Imja Lake, a vertical mixing is probably very weak because of the weakness of wind over lake. The heat transfer within the lake could occur throughout the depths because of the weak density stratification (Figure 3b).

3D numerical simulation of wind velocity over glacial lakes was performed, in order to know how the topography of end moraine affects a wind system over lakes. A 3D topographic model around Tsho Rolpa Lake is shown in Figure 5. This is set in a calculation domain of $\mathrm{x} \times \mathrm{y} \times \mathrm{z}=$ $7000 \mathrm{~m} \times 2000 \mathrm{~m} \times 400 \mathrm{~m}$ in size. The topography was made by using a topographic map of $1 / 50000$ scale made in 1997 and considering results of topographic surveys in the past. The glacier front and side moraine's top are $30 \mathrm{~m}$ high and $70 \mathrm{~m}$ high, respectively above the lake surface of $\mathrm{x} \times \mathrm{y}=$ $3100 \mathrm{~m} \times 400 \mathrm{~m}$ (or $1200 \mathrm{~m} \times 400 \mathrm{~m})$ in size. The height of end moraine above the lake surface was given at $0 \mathrm{~m}$ or $20 \mathrm{~m}$. The water depth of the lake is constant at $50 \mathrm{~m}$. Constant wind velocity of 5 $\mathrm{m} / \mathrm{s}$ was given as the typical velocity of a valley wind (Figure 3a). Standard air pressure is $0.6 \mathrm{~atm}$ and air density is $0.75 \mathrm{~kg} / \mathrm{m}^{3}$, considering highly mountainous conditions. I solved the equations of momentum and continuum under steady state by the finite difference method, in order to get air pressure $P$ and wind velocity $(u, v, w)$. The grid number is $\mathrm{x} \times \mathrm{y} \times \mathrm{z}=65 \times 50 \times 44$. Each calculation was continued until wind velocity at a point far from the topographic model reached to ca. $5 \mathrm{~m} / \mathrm{s}$.

Calculated results are shown as wind vectors at $2 \mathrm{~m}$ above the lake surface in Figure 6. The 2-m wind velocity ranges from 4.4 to $4.8 \mathrm{~m} / \mathrm{s}$ for the
FIGURE 4.

Conceptual of hydrodynamics in Tsho Rolpa Lake

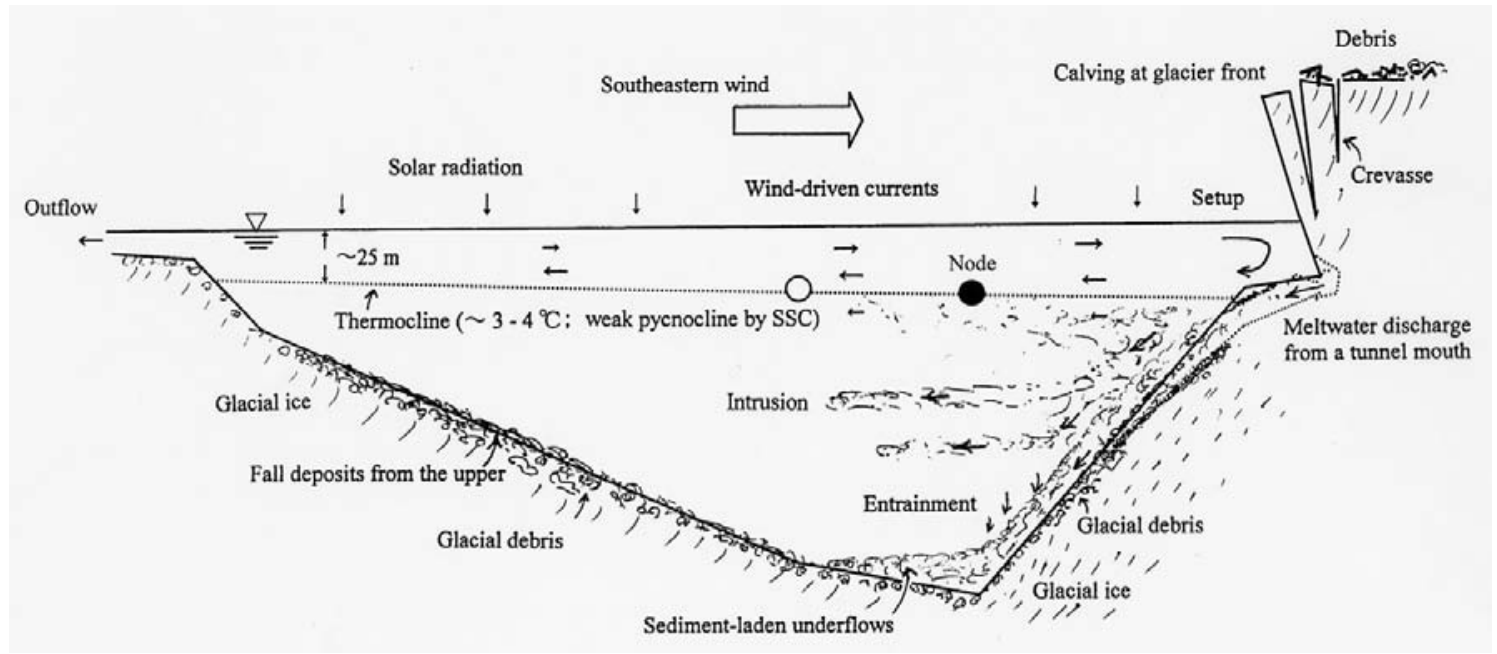


lake model $3100 \mathrm{~m}$ long with the end moraine's top leveled to the lake surface, but 2.6 to $3.0 \mathrm{~m} / \mathrm{s}$ for that $1200 \mathrm{~m}$ long (Figure 6ab). A decrease of fetch (leeward lake length) thus tends to decrease the wind velocity all over the surface. On the other hand, the wind velocity ranged over 1.1 to $3.2 \mathrm{~m} / \mathrm{s}$ for the model $3100 \mathrm{~m}$ long with the end moraine's top $20 \mathrm{~m}$ higher than the surface, and over 2.1 to $2.6 \mathrm{~m} / \mathrm{s}$ in a water area within $1200 \mathrm{~m}$ downwind of end moraine (Figure 6c). The topography of end moraine can thus affect greatly a wind-velocity distribution over lake. These calculated results suggest that the weak wind mixing in Imja Lake is due to the topographic feature of the plane end moraine ca. 10 to $20 \mathrm{~m}$ higher than the lake surface, in addition to the relatively shortfetch.

As a next step, hydrodynamics in Tsho Rolpa (Figure 4) will be reproduced by 3D numerical simulation. Moreover, the lake expansion by the melt of glacier ice in contact with the lake basin will be reproduced similarly, in order to clarify the lake expansion mechanism.

\section{References}

Chikita K, J Jha and TYamada. 1999. Hydrodynamics of a supraglacial lake and its effect on the basin expansion: Tsho Rolpa, Rolwaling Valley, Nepal Himalaya. Arctic, Antarctic and Alpine Research 31(1): 58-70

Chikita K, SP Joshi, J Jha and H Hasegawa. 2000: Hydrological and thermal regimes in a supraglacial lake: Imja, Khumbu, Nepal Himalaya. Hydrological Sciences Journal 45(4): 507-21

Chikita K, J Jha and TYamada. 2001: Sedimentary effects on the expansion of a Himalayan supraglacial lake. Global and Planetary Change 28: 23-34

Kadota $\mathrm{T}$ 1994. Report for the filed investigation on the Tsho Rolpa glacier lake, Rolwaling Valley, February 1993-June 1994. WECS Report, N551.489 KAD, 26pp

Sakai A, K Chikita and TYamada. 2000. Expansion of a moraine-dammed glacial lake, Tsho Rolpa, in Rolwaling Himal. Limnology and Oceanography 45(6): 1401-08

Yamada T. 1998. Glacier Lake and its outburst flood in the Nepal Himalaya. Monograph no. 1, Data Center for Glacier Research, Japanese Society of Snow and Ice, 96pp

YamadaT and CKSharma. 1993. Glacier lakes and outburst floods in the Nepal Himalaya. Snow and Glacier Hydrology (Proceedings of the Kathmandu Symposium, November 1992), IAHS Publication no. 218: 319-30

Yamada T, N Naito, S Kohshima, H Fushimi, F Nakazawa, T Segawa, J Uetake, R Suzuki, N Sato, Karma, IK Chhetri, L Gyenden, HYabuki and KChikita. 2004. Outline of 2002 -research activities on glaciers and glacier lakes in Lunana region, Bhutan Himalayas. Bulletin of Glaciological Research 21: 79-90

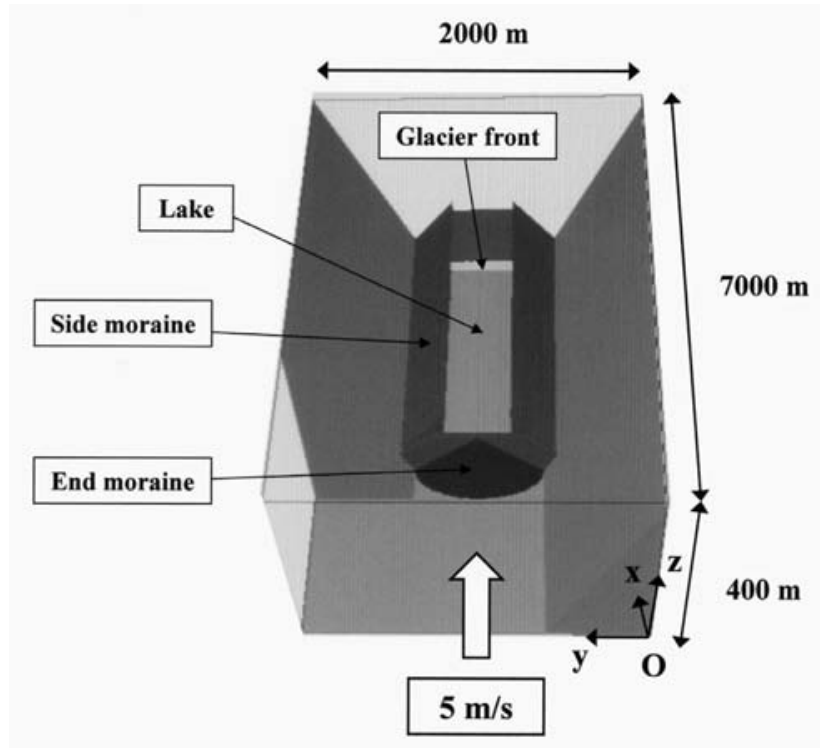

FIGURE 5. Topographic model around Tsho Rolpa Lake for numerical simulation

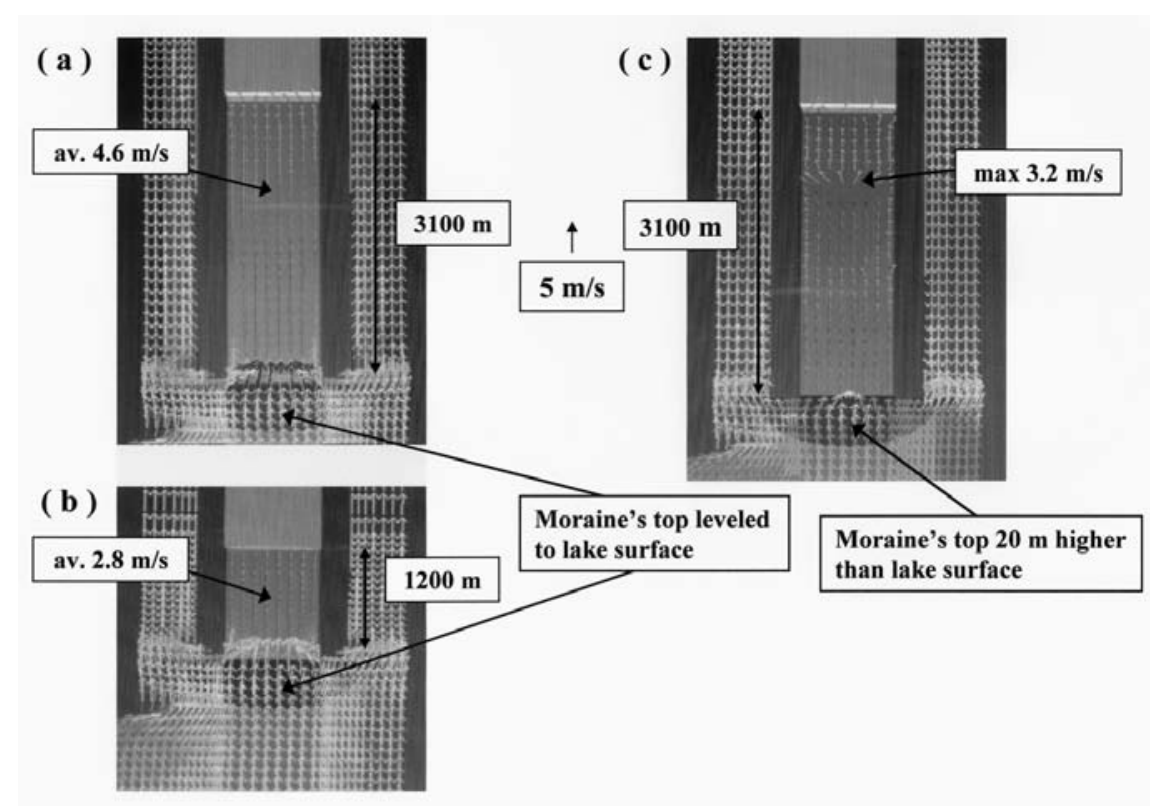

FIGURE 6. Calculated wind velocity at $2 \mathrm{~m}$ above the lake surface for lake models (a) 3100 $\mathrm{m}$ long and (b) $1200 \mathrm{~m}$ long with leveled to lake surface, and (c) $3100 \mathrm{~m}$ long with end moraine's top at $20 \mathrm{~m}$ above the surface 